\title{
Behavioural deviance in children with early treated phenylketonuria
}

\author{
J. E. STEVENSON, JANET HAWCROFT, MARY LOBASCHER, ISABEL SMITH, \\ O. H. WOLFF, AND P. J. GRAHAM
}

Departments of Child Psychiatry and Child Health, Institute of Child Health, London

SUMMARY A sample of 99 early treated phenylketonuric children showed higher levels of behavioural deviance than 197 matched controls. For boys this excess of behavioural deviance persisted when IQ was taken into account. For phenylketonuric girls however it was restricted to those with IQs $<70$. The type of behavioural deviance shown by the boys over the whole IQ range was predominantly neurotic. The levels of behavioural deviance found in phenylketonuric children were among the highest that have been reported for children with various handicapping conditions.

It has now been shown that early treatment of phenylketonuria (PKU) results in a reasonably full preservation of intellectual functioning, although there may be a failure to reach full cognitive potential (Berman and Ford, 1970; Hudson et al., 1970; Koch et al., 1973; Smith and Wolff, 1974). The behaviour and emotional development of early treated children has been less thoroughly investigated (Wood et al., 1967; Hackney et al., 1968; Siegel et al., 1968; Frankenburg et al., 1973). These aspects of personality development are of importance in children with PKU because of the inevitable stresses that they are likely to meet as a result of their highly artificial diet. The capacity to cope with this diet will depend on the child's own adjustment to an increasing extent as he gets older. A girl with PKU is particularly likely to face stress in her child-bearing years because of the likelihood of her giving birth to a handicapped child. This risk to the fetus is probably reduced if a low phenylalanine diet is given during pregnancy, although the diet should be introduced before conception and no guarantee of a normal outcome can be given. Finally, because of the higher rates of psychiatric

Departments of Child Psychiatry and Child Health, Institute of Child Health, London

J. E. STEVENSON, research fellow

ISABEL SMITH, research fellow

O. H. WOLFF, Nuffield professor of child health

P. J. GRAHAM, professor of child psychiatry

Department of Psychological Medicine, The Hospital for Sick Children, Great Ormond Street, London

MARY LOBASCHER, psychologist

Phenylketonuria Register Office, Alder Hey Children's Hospital, Liverpool

JANET HAWCROFT, research assistant disorder in children with brain dysfunction (Graham and Rutter, 1968), even children in whom PKU is treated early may have an increased risk of disturbance, however strictly the diet is enforced, because blood phenylalanine levels are bound to vary over a wider range than in the normal child. For these reasons it was thought worthwhile to investigate behavioural deviance in children with PKU.

\section{Patients and methods}

Newborn infants in the UK are tested for raised blood phenylalanine levels between the 6th and 14th day of life. The Medical Research Council and the Department of Health and Social Security maintain, initially at Alder Hey Hospital, Liverpool, and currently at the Institute of Child Health, London, a phenylketonuria register. Paediatricians and screening laboratories are asked to notify newly diagnosed cases and at yearly intervals paediatricians are asked to provide follow-up details. The organisation of the register has been described by Hudson and Hawcroft (1977). Paediatricians are asked to arrange for IQs to be measured in all the children at 4 years (Stanford Binet) (Terman and Merrill, 1960), and then at 8, 10, and 12 years (Wechsler intelligence scale for children) (Wechsler, 1949), within 6 weeks of each child's birthday; the psychologist carrying out the test at 8 years is also asked to give a Schonell graded word reading test (Schonell, 1955).

Since 1972 paediatricians have been requested to ask parents to complete a behaviour questionnaire (Rutter A scale) of known reliability and validity 
(Rutter et al., 1970b) when the child is 8 years old. At the same age, after obtaining parental permission, the child's class teacher is asked to complete a behaviour questionnaire (Rutter B scale) (Rutter, 1967) on the patient and, as controls, on 2 children in the same class of the same sex and nearest in age to the patient. The information on the control children is provided anonymously.

The Rutter parent and teacher scales consist of descriptions of behaviour rated as 'certainly applies', 'applies somewhat', and 'doesn't apply' (scored 2, 1 , and 0 respectively). The teacher scale has 26 such items and the parent scale 18 ; the parent scale has, in addition, 13 items on health and habits (similarly scored 2, 1, and 0 ). Children scoring 9 or more on the teacher scale or 13 or more on the parent scale, have been shown by Rutter to have a higher risk of psychiatric disorder than those with lower scores. Furthermore, the deviant behaviour shown by children with high scores can be classified into 3 diagnostic types-antisocial, neurotic, or mixeddepending on the ratings of relevant individual items (Rutter et al., 1970b). In the present study because numbers were small, antisocial and mixed groups are combined in the analysis.

The children in the present study are the first 99 children with early treated PKU on the register whose parents had completed a behaviour questionnaire. For 38 other early treated cases no parent behaviour questionnaire had been obtained. Teacher behaviour questionnaire data are also available for this sample and for their 197 matched control children (data were missing for one control child). IQ data were obtained for a subsample of 86 PKU children. Parent scale ratings and IQs were not obtained on control children.

\section{Results}

Overall rates of behavioural deviance on the teacher Rutter scale for patient and control groups. Table 1 shows the numbers of patient and control children that were identified by the teacher scale as being behaviourally deviant. More $(40 \%)$ of the patient sample were behaviourally deviant than the control group $(20 \%)\left(\chi^{2}=13.50, \quad \mathrm{df}=1, \quad \mathrm{P}<0.001\right)$. A greater proportion of the total patient sample $(22 \%)$ showed neurotic deviance than did the control group $(8 \%)(Z=3.59, P<0.001)$. The proportions in the 2 groups showing antisocial deviance were not significantly different.

There is a difference between the boys and girls in the patient sample. The male patients showed more frequent behavioural deviance than the controls $\left(\chi^{2}=21.38, \mathrm{df}=1, \quad \mathrm{P}<0.001\right)$ and the proportion of male patients with neurotic deviance $(31 \%)$ was greater than that of the controls $(4 \%)$ $(\mathrm{Z}=2 \cdot 15, \mathrm{P}<0.05)$; the proportion of male patients with antisocial deviance although twice that of the controls was not significantly different. For female patients neither the overall rate of deviance nor the rate of antisocial or neurotic deviance was significantly greater than for controls. The greater behavioural deviance among the children with PKU is due mainly to the neurotic deviance among the boys.

Parental Rutter scale rates of deviance for the patient group. The children with PKU showed the same pattern of deviance on the parental scale as was found on the teacher scale. The parents identified fewer children as deviant $(24 \%)$ than the teachers $(40 \%)\left(\chi^{2}=5.91, \mathrm{df}=1, \mathrm{P}<0.02\right)$ but, like the teachers, they more often identified neurotic deviance than antisocial deviance. On the parent scale boys (33\%) again more often showed deviance than girls $(17 \%)$ and although the rates of antisocial deviance were similar for boys $(11 \%)$, and girls $(7 \%)$, the parents identified more boys $(22 \%)$ than girls $(9 \%)$ as neurotic. None of these sex differences is however significant.

Table 1 Rates of behavioural deviance on teacher Rutter scale in patients and controls

\begin{tabular}{|c|c|c|c|c|c|}
\hline & \multirow{4}{*}{$\frac{\text { Not deviant }}{\text { No. }(\%)}$} & \multirow{4}{*}{$\frac{\text { Deviant }}{\text { No. }(\%)}$} & \multicolumn{2}{|c|}{ Type of deviance } & \multirow{4}{*}{ Total } \\
\hline & & & \multirow{3}{*}{$\begin{array}{l}\begin{array}{l}\text { Antisocial } \\
\text { and mixed }\end{array} \\
\text { No. }(\%)\end{array}$} & \multirow{3}{*}{$\frac{\text { Neurotic }}{\text { No. (\%) }}$} & \\
\hline & & & & & \\
\hline & & & & & \\
\hline \multicolumn{6}{|l|}{ Controls } \\
\hline Total & $157(80)$ & $40(20)$ & $25(12)$ & $15(8)$ & 197 \\
\hline Boys & 74 (83) & $15(17)$ & $11(12)$ & $4(4)$ & 89 \\
\hline Girls & $83(77)$ & $25(23)$ & 14 (13) & $11(10)$ & 108 \\
\hline \multicolumn{6}{|l|}{ Patients } \\
\hline Total & $59(60)$ & $40(40)$ & $18(18)$ & $22(22)$ & 99 \\
\hline Boys & $20(44)$ & $25(56)$ & $11(24)$ & $14(31)$ & 45 \\
\hline Girls & $39(72)$ & $15(28)$ & $7(13)$ & $8(15)$ & 54 \\
\hline
\end{tabular}


Rates of behavioural deviance on teacher Rutter scale for children with different IQ levels within the patient group. The mean IQ at 8 years was for boys 89.74 (SD 19.33) and for girls 83.25 (SD 17.72). The product moment correlation between the total score on the teachers scale and IQ for boys was $-0.29(\mathrm{P}<0.05)$ and for girls $-0.42(\mathrm{P}<0.01)$.

Table 2 shows that the rates of behavioural deviance for the PKU children vary with IQ measured at 8 years. The IQs of the control children were not measured, so comparison was made between patients in each IQ group and controls undifferentiated as to IQ. PKU boys with IQs $<70$ show a greater incidence of behavioural deviance $(66 \cdot 7 \%)$ than controls $(17 \%)\left(\chi^{2}=9 \cdot 27, \mathrm{df}=1\right.$, $\mathbf{P}<0.01)$ and are more likely, if deviant, to show neurotic deviance (Fisher's exact probability test $P=0.03$ ). Patient boys with IQs in the range 70-99 again show more deviance $(62 \%)$ than controls $\left(\chi^{2}=15 \cdot 88, \mathrm{df}=1, \mathrm{P}<0.001\right)$ but with no significant difference in the type of deviance. Those patient boys with above average IQs (IQ $\geqslant 100)$ show more deviance $(41.7 \%)$ than controls, although this difference is not significant. However those PKU boys with IQs $>100$, if deviant, are more likely than the controls to be neurotic (Fisher's exact probability test $P=0.05$ ).

For the PKU girls with IQs $<70$ there is more behavioural deviance $(75 \%)$ than in the control girls $(23 \%)\left(\chi^{2}=11 \cdot 86, \mathrm{df}=1, \mathrm{P}<0.001\right)$, but no significant difference in the type of deviance. PKU girls with IQs in the range 70-99 show no significant differences in the rates of deviance or type of deviance from the control girls. However, for PKU girls with average and above average IQs (IQ $\geqslant 100$ ) there were no cases of behavioural deviance, compared with $23 \%$ for the control girls $\left(\chi^{2}=4 \cdot 21\right.$, $\mathrm{df}=1, \mathrm{P}<0 \cdot 01)$.

\section{Discussion}

The results of the study show that PKU children had significantly higher rates of behavioural deviance than matched controls. The high rate of deviance however is restricted to boys, and to girls with IQs $<70$. Previous work with the Rutter scales has demonstrated that behavioural deviance is closely related to the presence of psychiatric disorder, defined as a significantly handicapping behavioural or emotional disturbance (Rutter, 1967; Rutter et al., 1970b). The high rate of deviance found among the PKU children of this study probably indicates that these children have a higher rate of psychiatric disorder than normal children. These findings are not in agreement with those of Siegel et al. (1968) who used an unstandardised school behaviour profile and compared PKU children with matched controls, finding no greater amount of behavioural deviance in 13 PKU children.

In the present study $20 \%$ of control children were rated as behaviourally deviant on the teacher questionnaire. This percentage is high compared with that found in the Isle of Wight (IOW) study (Table 3) but is almost identical with the figure of $19.1 \%$ found in a study of randomly selected 10 year-old children living in an inner London borough (Rutter et al., 1975), which is probably representative of children living in big cities in the UK. We do not have data on the urban/rural distribution of the PKU children but it is likely that, as with the general population, most of them live in urban areas.

The rate of $40 \%$ deviance on the teacher questionnaire for the children with PKU is higher than any other group of children so far reported, except for IOW children suffering from combined lesions above the brain stem (usually cerebral palsy) with or without epilepsy (Table 3 ). The rate of $24 \%$ deviance

Table 2 Rates of behavioural deviance on teacher Rutter scale for patients with different IQ levels

\begin{tabular}{|c|c|c|c|c|c|}
\hline \multirow{4}{*}{ Patients } & \multirow{4}{*}{$\frac{\text { Not deviant }}{\text { No. }(\%)}$} & \multirow{4}{*}{$\frac{\text { Deviant }}{\text { No. }(\%)}$} & \multicolumn{2}{|c|}{ Type of deviance } & \multirow{4}{*}{ Total } \\
\hline & & & \multirow{2}{*}{$\begin{array}{l}\text { Antisocial } \\
\text { and mixed }\end{array}$} & \multirow[b]{2}{*}{ Neurotic } & \\
\hline & & & & & \\
\hline & & & No. $(\%)$ & No. $(\%)$ & \\
\hline \multicolumn{6}{|l|}{ Boys } \\
\hline $\begin{array}{r}1 Q<70 \\
70-99 \\
\geqslant 100\end{array}$ & $\begin{array}{l}3(33) \\
8(38) \\
7(58)\end{array}$ & $\begin{array}{r}6(67) \\
13(62) \\
5(42)\end{array}$ & $\begin{array}{l}1(11) \\
9(43) \\
1(8)\end{array}$ & $\begin{array}{l}5(56) \\
4(19) \\
4(33)\end{array}$ & $\begin{array}{r}9 \\
21 \\
12\end{array}$ \\
\hline \multicolumn{6}{|l|}{ Girls } \\
\hline $\begin{array}{r}1 Q<70 \\
70-99 \\
\geqslant 100\end{array}$ & $\begin{array}{c}3(25) \\
19(83) \\
9(100)\end{array}$ & $\begin{array}{l}9(75) \\
4(17) \\
0(0)\end{array}$ & $\begin{array}{l}6(50) \\
1(4) \\
0(0)\end{array}$ & $\begin{array}{l}3(25) \\
3(13) \\
0(0)\end{array}$ & $\begin{array}{r}12 \\
23 \\
9\end{array}$ \\
\hline
\end{tabular}


Table 3 Rates of behavioural deviance in various populations and groups with a range of disorders

\begin{tabular}{|c|c|c|c|c|}
\hline \multirow[t]{2}{*}{ Population/groups } & \multirow[t]{2}{*}{ No. } & \multirow{2}{*}{$\begin{array}{l}\text { Age } \\
\text { (years) }\end{array}$} & \multicolumn{2}{|c|}{$\%$ deviant on } \\
\hline & & & $\begin{array}{l}\text { Teacher } \\
\text { scale }\end{array}$ & $\begin{array}{l}\text { Parent } \\
\text { scale }\end{array}$ \\
\hline $\begin{array}{l}\text { PKU } \\
\text { PKU controls } \\
\text { IOW total population }\end{array}$ & $\begin{array}{r}99 \\
197\end{array}$ & $\begin{array}{l}8 \\
8\end{array}$ & $\begin{array}{l}40 \\
20\end{array}$ & $\frac{24}{-}$ \\
\hline $\begin{array}{l}\text { (Rutter et al., 1970b) } \\
\text { Inner London Borough } \\
\text { total population }\end{array}$ & 2199 & $10-11$ & $7 \cdot 1$ & $6 \cdot 8$ \\
\hline $\begin{array}{l}\text { (Rutter et al., 1975) } \\
\text { Asthma }\end{array}$ & 1689 & 10 & $19 \cdot 1$ & - \\
\hline $\begin{array}{l}\text { (Graham et al., 1967) } \\
\text { Miscellaneous other } \\
\text { physical disorders }\end{array}$ & 65 & $9-11$ & $10 \cdot 7$ & $10 \cdot 5$ \\
\hline $\begin{array}{l}\text { (Rutter et al., 1970a) } \\
\text { Uncomplicated epilepsy }\end{array}$ & 127 & $10-12$ & $12 \cdot 6$ & $9 \cdot 6$ \\
\hline $\begin{array}{l}\text { (Rutter et al., 1970a) } \\
\text { Lesions above brain stem } \\
\text { (no fits) }\end{array}$ & 55 & $5-14$ & $26 \cdot 7$ & $24 \cdot 5$ \\
\hline $\begin{array}{l}\text { (Rutter et al., 1970a) } \\
\text { Lesions above brain stem }\end{array}$ & 22 & $5-14$ & $41 \cdot 7$ & $23 \cdot 8$ \\
\hline $\begin{array}{l}\text { (fits) (Rutter et al., 1970a) } \\
\text { Brain lesion }\end{array}$ & 12 & $5-14$ & $38 \cdot 5$ & $30 \cdot 0$ \\
\hline $\begin{array}{l}\text { (Seidel et al., 1975) } \\
\text { Peripheral i.e. lesions } \\
\text { not brain }\end{array}$ & 33 & $5-14$ & 30 & - \\
\hline (Seidel et al., 1975) & 42 & $5-14$ & 10 & 一 \\
\hline
\end{tabular}

on the parent questionnaire is also similar in children with brain lesions and those with uncomplicated epilepsy and is again higher than all others reported. However the children in the present study were younger than those of other studies, and a previous study (Graham and Rutter, 1973) showed that younger children tend to have higher rates of deviance when measured by the Rutter scales.

Another factor which may have contributed to the high rates of deviance observed in children with PKU is their low IQs. Previous work with normal children has shown a relationship between IQ and behavioural deviance, particularly for the teacher scale. Children with intellectual retardation (IQ $<70$ ) on the IOW (Rutter et al., 1970b) showed deviance rates of $41 \%$ with roughly equal proportions of neurotic and antisocial deviance, and children with psychiatric disorder have been shown to have slightly lower IQs than normal controls (Rutter et al., 1970b); however the effect is slight (equivalent to about 5 IQ points), and for boys it is restricted to those with antisocial disorders. The high rate of deviance of PKU girls is confined to those with IQs $<70$, and boys with IQs $<70$ showed a particularly high rate of deviance. However boys with IQs $>70$ also showed significantly more frequent behavioural disturbance; this together with the high rate of neurotic disorder among the boys suggests that low IQs cannot be the only explanation for the behavioural deviance.

It is not possible from these data to find the cause for the high rate of behavioural deviance among
PKU children, although there are several possibilities, namely: (1) direct effect of raised blood phenylalanine levels on brain cell metabolism producing disordered functioning, (2) effect of phenylalanine levels on brain growth and development in early life, (3) psychological effects of a very abnormal diet for a long period on the child himself or via its effect on family relationships (Keleske et al., 1967; Sibinga and Friedman, 1971; Bentovim, 1976), and (4) a genetic mechanism linking the gene producing PKU with others producing a vulnerability to psychiatric disturbance. Psychiatric disturbance, which the high rate of behavioural deviance implies, is a handicap which the treated child (particularly boys) with PKU is more likely to show than children in the general population; those managing the condition may find it helpful to be aware of this fact.

The Medical Research Council and Department of Health and Social Security provide financial support for the register. We are grateful to the paediatricians, psychologists, parents, and children who have cooperated in the study which is ongoing.

We wish to pay tribute to Dr F. Hudson who, until his death in 1976, was responsible for the running of the PKU register and whose enthusiasm and dedication are responsible for the register now providing a valuable research tool, which should allow much further work aimed at the improvement of the management of patients with PKU.

\section{References}

Bentovim, A. (1976). Impact on family coping when phenylketonuria is treated by dietary means from infancy (abstract). Archives of Disease in Childhood, 51, 810.

Berman, J. L., and Ford, R. (1970). Intelligence quotients and intelligence loss in patients with phenylketonuria and some variant states. Journal of Pediatrics, 77, 764-770.

Frankenburg, W. K., Goldstein, A. D., and Olson, C. O. (1973). Behavioral consequences of increased phenylalanine intake by phenylketonuric children: a pilot study describing a methodology. American Journal of Mental Deficiency, 77, 524-532.

Graham, P. J., Rutter, M. L., Yule, W., and Pleiss, I. B. (1967). Childhood asthma: a psychosomatic disorder? Some epidemiological considerations. British Journal of Preventive and Social Medicine, 21, 78-85.

Graham, P. J., and Rutter, M. (1968). Organic brain dysfunction and child psychiatric disorder. British Medical Journal, 3, 695-700.

Graham, P. J., and Rutter, M. (1973). Psychiatric disorder in early adolescence: a follow-up study. Proceedings of the Royal Society of Medicine, 66, 1226-1230.

Hackney, I. M., Hanley, W. B., Davidson, W., and Lindsao, L. (1968). Phenylketonuria: mental development, behavior and termination of low phenylalanine diet. Journal of Pediatrics, 72, 646-655.

Hudson, F. P., Mordaunt, V. L., and Leahy, I. (1970). Evaluation of treatment begun in the first three months of life in cases of phenylketonuria. Archives of Disease in Childhood, 45, 5-12. 


\section{Stevenson, Hawcroft, Lobascher, Smith, Wolff, and Graham}

Hudson, F. P., and Hawcroft, J. (1977). The phenylketonuria register for the United Kingdom. In Medico-social Management of Inherited Metabolic Disease, p. 217. Edited by D. N. Raine. MTP Press: Lancaster.

Keleske, L., Solomon, G., and Opitz, E. (1967). Parental reactions to phenylketonuria in the family. Journal of Pediatrics, 70, 793-798.

Koch, R., Dobson, J. C., Blaskovics, M., Williamson, M. L., Ernest, A. E., Friedman, E. G., and Parker, C. E. (1973). Collaborative study of children treated for phenylketonuria. In Treatment of Inborn Errors of Metabolism, pp.3-18. Edited by J. W. T. Seakins, R. A. Saunders, and $\mathrm{C}$. Toothill. Churchill Livingstone: Edinburgh.

Rutter, M. (1967). A children's behaviour questionnaire for completion by teachers: preliminary findings. Journal of Child Psychology and Psychiatry and Allied Disciplines, 8, 1-11.

Rutter, M., Cox, H., Tupling, C., Berger, M., and Yule, W. (1975). Attainment and adjustment in two geographical areas. I. The prevalence of psychiatric disorder. British Journal of Psychiatry, 126, 493-509.

Rutter, M., Graham, P. J., and Yule, W. (1970a). A Neuropsychiatric Study in Childhood. Heinemann: London.

Rutter, M., Tizard, J., and Whitmore, K., editors (1970b). Education, Health, and Behaviour. Longmans: London.

Schonell, F. J. (1955). Reading and Spelling Tests. Handbook of Instructions. Oliver and Boyd: Edinburgh.

Seidel, U. P., Chadwick, O. F. D., and Rutter, M. (1975). Psychological disorders in crippled children. A comparative study of children with and without brain damage. Developmental .Medicine and Child Neurology, 17, 563-573.

Sibinga, M. S., and Friedman, C. J. (1971). Complexities of parental understanding of phenylketonuria. Pediatrics, 48, 216-224.

Siegel, F. S., Barlow, B., Fisch, R. O., and Anderson, V. E. (1968). School behaviour profile ratings of phenylketonuric children. American Journal of Mental Deficiency, 72, 937-943.

Smith, I., and Wolff, O. H. (1974). The natural history of phenylketonuria and influence of early treatment. Lancet, 2, 540-544.

Terman, L. M., and Merrill, M. A. (1960). Stanford Binet Intelligence Scale. Manual for the Third Revision, Form $L-M$. Harrap: London.

Wechsler, D. (1949). Wechsler Intelligence Scale for Children. Psychological Corporation: New York.

Wood, A. C., Jr, Friedman, C. J., and Stiesel, I. M. (1967). Psychosocial factors in phenylketonuria. American Journal of Orthopsychiatry, 37, 671-679.

Correspondence to Dr J. E. Stevenson, Department of Child Psychiatry, Institute of Child Health, The Hospital for Sick Children, Great Ormond Street, London WC1N 3JH.

Received 11 April 1978 